\title{
The Use Extract of Siam Leaf Eupatorium odoratum L. as Alternative Material In Lowering Blood Glucose
}

\author{
Ulfah Nur Amaliah, Eva Johannes, Munif S. Hassan \& Elis Tambaru \\ Departement of Biology, Faculty Mathematic and Natural Science, Hasanuddin University, \\ Makassar
}

\begin{abstract}
The use of medicine as oral hypoglycemic and insulin have some limitation, the treatment for diabetics needs more expensive cost relatively because it uses in the long term and can give the unwanted side effect. At the recent time, one of the conducted efforts is by using the plant as alternative medicine. This research aims to know the potential of leaves' extract and to know the effectiveness of siam weed leaves extract's dosage which most effectivein lowering the level of blood glucose in mice which is induced by alloxan. On this research, anti-diabetic effect of siam weed leaves was observed to male mice which had been induced by alloxan until the level of blood glucose $>200 \mathrm{mg} / \mathrm{dl}$. The given treatment orally was conducted during seven days with three variations of dosage concentration of infused extract, they are $5 \%, 10 \%$ and $20 \%$. Furthermore, it was also used the comparison i.e. infused extract of cinnamon bark with $10 \%$ concentration. Data analyse used SPSS 23.0 program with one way ANOVA then was continued by using Duncan test. The research result shows that the siam weed leaves extract with dosage concentration $5 \%, 10 \%$ and $20 \%$ can decrease blood glucose level on mice that have suffered hyperglycemia and most effective on $20 \%$. Thus, it can be concluded that siam weed leaves extract have the potential in lowering blood glucose.
\end{abstract}

Article History

Received 07 January 2019

Accepted 24 June 2019

\section{Keyword}

Anti-diabetic, Infused extract, Eupatorium odoratum Blood glucose

\section{Introduction}

Hyperglycemia is the condition where the blood glucose level exceeds normal limits. The increasing of glucose level in blood plasma (hyperglycemia) is one of bases in diagnosis of diabetes mellitus. It is caused by the abnormality of metabolism, specifically the abnormality on carbohydrate metabolism (Wulandari, 2010). The treatment on people with diabetes mellitus needs relative more expensive cost because it uses in long term and can give unwanted side effect. Furthermore, the medicine likes as oral hypoglycemic and insulin have some limitation. Oral hypoglycaemic medicine in sulfonylurea group can cause gastrointestinal disorder such as qualm, diarrhea, stomach-ache, and hyper secretion of gastric acid (Jung et al. 2006 in Sakika et al. 2015; Dalimartha and Adrian, 2012 in Pasaribu et al. 2012). Therefore, it needs the effective medicine, the relative low side effect, the relative 
cheap and affordable cost. One of conducted efforts is by using plant as alternative medication. It encourages the amount of research about the plants which have the potential to decrease blood glucose level, one of the plant which has the potential as the lowering of blood glucose is siam weed Eupatorium odoratum L.

Siam weed Eupatorium odoratum L. is one of the most abundant weed plants. Weed is one of plant pest organism which inhibit the growth, development, and productivity of cultivated plants. The existence of weeds at agriculture area generally gives the negative effect toward the plants, because weeds have the high competitive capacity thus enabling light, $\mathrm{CO}_{2}$, water, nutrient, and space to grow competition which were used simultaneously (Riry, 2008 in Palijama et al. 2012), because of its abundant availability, then it is very potential to be utilized.

Siam weed includes to Asteraceae family, traditionally is used to healing the wounds and infection, headache, diarrhea, astringent, antispasmodic, antihypertensive, antiinflammation and diuretic (Vital and Rivera, 2009 in Yenti et al. 2014). Siam weed leaves contain some main compounds such as tannin, flavonoid, saponin, and steroid. Essentials oil of siam weed leaves has a substance of $\boldsymbol{\alpha}$-pinene, cadinene, camphora, limonene, $\beta$ caryophylleneand candinol isomer (Benjamin, 1987 in Yenti et al. 2014). The research of Alisi, et al, (2011), in Marianne et al, (2014), explained that siam weed has the potential as antioxidant and able to prevent free radicals which is believed as the cause of various degenerative disease and premature aging. And also there was a research which claimed that these siam weed leaves' extract able to be as anti-diabetic (Murthy and Kiran, 2012; Raman et al. 2012; Marianne et al. 2014). Based on that, then need to be conducted the research about the potential of siam weed leaves' extract to know the bioactive compounds which contained in that plant, thus made as one of alternative in lowering the level of blood glucose.

\section{Materials and Methods}

Tools

The tools were used knife/hook, animal raising cage, gloves, drinking water place, analytical balance, blender, jar, mess, oral sonde, mortar and pestle, syringe, syringe $1 \mathrm{cc}$, stirring rod, spatula, wiper, digital scales, hot plate, stirrer, infused pen, Buchner funnel, sprayers, thin layer chromatography plate, glucometer (Nesco ${ }^{\circledR}$ ), measuring cup, surgical scissor, measuring flask, vial bottle, alcohol thermometer 10-110 $\mathrm{\circ}$, and glass tools (Phyrex).

\section{Materials}

The materials which were used are siam weed leaves Eupatorium odoratumL. which were obtained from Kassiloe Village, Labakkang District, Pangkep Regency. The material were used aquades, dragendorf reagent, chloride acid $(\mathrm{HCl})$, CarboxiMetilCellulosa $\mathrm{Na}$ ( $\mathrm{Na}-\mathrm{CMC}$ ), standart mice' food, glibenclamide5 $\mathrm{mg}$, alloxan monohydrate, cinnamon bark Cinnamomunburmanii, glucotest stripe, aluminum foil, picric acid, API (Aqua Pro Injection), filter paper, cling wrap, and label. The used test animals are male mice Balb $C$ around 18 mice with the age 3-4 months, the average body weight 20-35 gr, healthy and behave normally, which were obtained from Bio pharmacy Laboratory of Pharmacy Faculty, Hasanuddin University. Before used, the mice were acclimatized during 7 days with laboratory condition. 


\section{Ethical Clearance}

This research had been evaluated and gained the ethical approval recommendation of Medical Research Ethical Committee, Medical Faculty, Hasanuddin University, No.318/H4.8.4.5.31/PP36-KOMETIK/2018, 23th April 2018.

Research framework used complete randomized design with the used treatment group namely:

K1 : Negative Control (Na-CMC 1\%)

K2 : Positive Control (glibenclamide) $0,083 \mathrm{mg} / \mathrm{kgBB}$

K3 : Comparison Group (Cinnamon infused extract 10\%)

K4 : Treatment I Group (Siam weed leaves infused extract 5\%)

K5 : Treatment II Group (Siam weed leaves infused extract 10\%)

K6 : :Treatment III Group (Siam weed leaves infused extract 20\%)

\section{Making Infused Extract of siam weed Leaves}

Siam weed leaves were washed and air dried did not under direct sunlight during 5 days until the leaves become brown. Furthermore, the extraction done by using infused method. The process of making extraction that is the sample mashed into powder. After that, it was sifted by using mess in order to gain the powder in the certain subtle degree. After that, it put into the top infused pan then was poured with water as much $100 \mathrm{~mL}$, the bottom of pan was filled with water until full then was heated until the water in the pan boiled. Furthermore, the temperature of extract in the pan was measured by using alcohol thermometer until its temperature gained $90^{\circ} \mathrm{C}$. After gained $90^{\circ} \mathrm{C}$ temperature, waited during 15 minutes, while occasionally steering. The result of infusion was filter while still hot by using Buchner funnel which coated with filter paper until gained the filtrate. The filtrate was the extract of siam weed leaves. The making of infusion's result with concentration $10 \%$ then the powder of leaves were weighed was 10 grams then were added water with volume $100 \mathrm{Ml}$., the it will be gained the concentration 10\% (Kusumaningrumet al. 2013). To make the infusion result with concentration $5 \%$ and $20 \%$ were made with similar way, by using 5 grams and 20 grams powder of siam weed leaves (Radiansah, 2013).

\section{Phytochemical Test of Infused Extract of siam weed Leaves}

After gained the infused extract of siam weed leaves, then conducted phytochemical analysis This phytochemical analysis was conducted in order the contained compounds of infused extract in siam weed leaves can be known. Phytochemicaltest was based on Harborne (1996) in Halim et al. (2015), to know the existence of active compounds such as alkaloid, flavonoid, saponin, and tannin. This phytochemical test was conducted by using tube test and thin layer chromatography plate test which was given reagent appropriate with the wanted compounds to be gained then was seen the occurrence of color change.

\section{Treatment toward Animal Test by Using Alloxan Induced Method}

The animals which were used as much 18 male mice in where divided into six groups. Before conducting the test of anti-diabetic effect, the tested animals were fasted during 8 hours. After fasted, the level of blood glucose of all mice was observed to determine blood glucose level of early fasting (GDPO). After that, induced by alloxan in dosage 3,5 $\mathrm{mg} / \mathrm{kgBBsubcutaneously.} \mathrm{Then} \mathrm{let} \mathrm{it} \mathrm{during} 3 \times 24$ hours until occurring the increasing effect of stable blood glucose' level (Marianne et al. 2014). Furthermore, was conducted the measurement of fasting blood glucose' level (GDP1), the mice which had been experienced 
the increasing of blood glucose' level ( $>200 \mathrm{mg} / \mathrm{dl}$ ) were clarified hyperglycemic, in this case, it was ready to be given the treatment. The treatment was given by giving test supply (the infused extract of siam weed leaves) orally (p.o) once per day during 7 days, with the dosage concentration of extract respectively $5 \%, 10 \%$ and $20 \%$. The level of blood glucose $(\mathrm{mg} / \mathrm{dl})$ were measured at the early (before treatment), after inducing alloxan (post-alloxan), and the fasting blood glucose' level after 7 days treatment (GDP2) on each group (Marianne et al. 2014). The parameter are the occurrence of decreasing blood glucose' level after the animals became diabetics, compared to the negative control (Na-CMC 1\%), positive control (glibenclamide) and comparison (infused extract of cinnamon bark). Each of test group used 3 mice.

\section{Examining The Level of Blood Glucose}

The level of blood glucose $\left(\mathrm{mg} / \mathrm{dl}\right.$ ) was determined by using glucometer (NesCo ${ }^{\circledR}$ Multicheck 1). Glucometer was activated, and then was put chip and strip on the tool. The blood of mice were taken from the part of their tails then were dropped on the tip of strip and automatically the level of blood glucose will appear on the monitor screen.

\section{Data analysis}

Data analysis was processed statistically by using software test SPSS 23.0 for Windows. The measurement result of all parameters in this research were analyzed statistically by using one way ANOVA, was conducted the continued test by using Duncan test

\section{Results and Discussion}

\section{Phytochemicaltest of infused extract on siam weed leaves}

The extract was obtained through infusion method by using water solvent (aquades). The process of extract making observed excessively in temperature and making time to minimalize the damage on the compound which contained in siam weed leaves, specifically on the heating process. Phytochemical analysis was conducted qualitatively to know the compound that has the role as anti-diabetic. The result of photochemistry analysis of infused extract can be seen as the following:

Table 3. Result of extract photochemistry analysis

\begin{tabular}{lllll}
\hline Numb. & The sort of testing & Reagent & Result & Note \\
\hline 1. & Flavonoid & Sitroborat & Form the green colour + \\
2. & Saponin & The heat & Form the stable foamas \\
& water $+\mathrm{HCl}$ & high as 1-3 cm & + \\
4. & Alkaloid & Dragendorff & Form the red-brown colour + \\
\hline
\end{tabular}

Note: $(+)=$ contained testing compound

$(-)=$ did not contain testing compound 


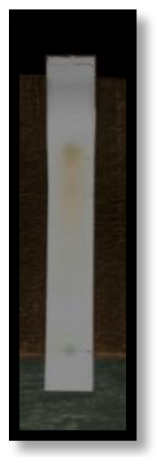

(a)

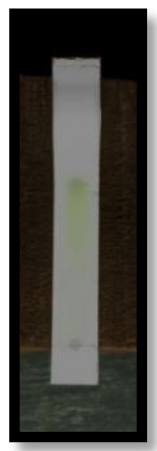

(b)

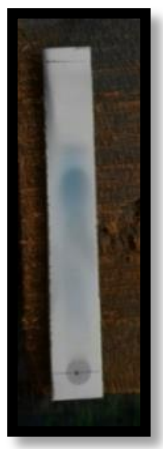

(c)

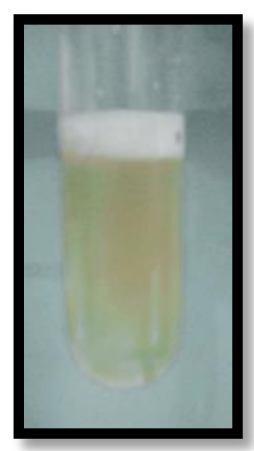

(d)

\section{Note:}

(a): Test result of Alkaloid,

(b): Test result of

Flavonoid,

(c): Test result of Tannin,

Figure 1. Result of extract phytochemical analysis

According to Prameswari et al. (2014), from the fourth compound, alkaloid and flavonoid are the natural active compound which known have hypoglycemic activity. Flavonoid is one of secondary metabolic compoundwhich can be found on the plants tissue, Can has the rule as anti-oxidative compound by giving one of its hydrogen atom (Redha, 2010). Tannin is the component of very complex organics substance, consisted of phenolic compound which hard to be separated and is the secondary metabolite active compound which has some benefits such as astringent, antidiarrheal, antibacterial, and biological antioxidant (Malangngi et al. 2012). The function of tannin as astringent can pucker up the epithelium of small intestine's wall thus decreases the absorption of food essence and inhibits the intake of glucose in blood (Prameswari et al. 2014). Saponin (triterpenes) based on Kirwanto (2014), it works in similar activity with insulin reaction, thus can take blood glucose into cells. Moreover, according to Prameswari et al. (2014), alkaloids compound works by stimulating hypothalamus to increase the secretion Growth Hormone Releasing Hormone $(\mathrm{GHRH})$, thus the secretion of Growth Hormone (GH) on hypophise increased. The high level of GH can stimulate the liver to secrete Insulin-like Growth Factor-1 (IGF-1). IGF-1 has the effect in inducing hypoglycemia and decreasing gluconeogenesis thus the level of blood glucose and the need of insulin lowered.

\section{The Level Of Blood Glucose After Treatment}

Table 4. The influence of giving Infused Extract from Siam Weed leaves Toward lowering the level of blood glucose on male mice

\begin{tabular}{ccccccc}
\hline \multirow{2}{*}{ Numb. } & Treatment & N & \multicolumn{3}{c}{$\begin{array}{c}\text { The Average Level of Blood Glucose from } \\
\text { Tested Animals (mg/dL) }\end{array}$} & \multirow{2}{*}{$\begin{array}{c}\text { GDP1-GDP2 } \\
\text { (mg/dL) }\end{array}$} \\
\cline { 3 - 5 } & & & GDP0 & GDP1 & GDP2 & \\
\hline 1. & K1 & 3 & 74,6 & 254 & 238,6 & 68 \\
2. & K2 & 3 & 83,3 & 213,6 & 79 & 134,6 \\
3. & K3 & 3 & 76,3 & 426 & 137 & 289 \\
4. & K4 & 3 & 96 & 486,3 & 296 & 190,3 \\
5. & K5 & 3 & 72,6 & 222,6 & 132,3 & 90,3 \\
6. & K6 & 3 & 67,6 & 382,3 & 137,6 & 244,6 \\
\hline
\end{tabular}




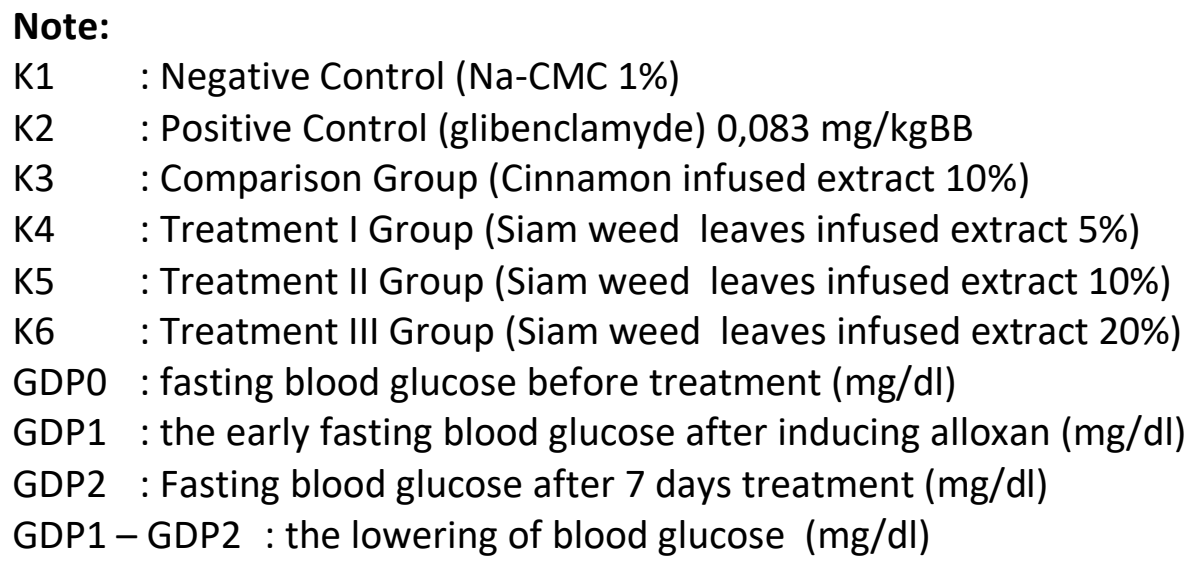

The result of measuring blood glucose' level of mice before and after treatment (table 4), can be drawn into histogram which served the average level of blood glucose of mice, before treatment, after inducing alloxan and also after 7 days of given treatment, as following:

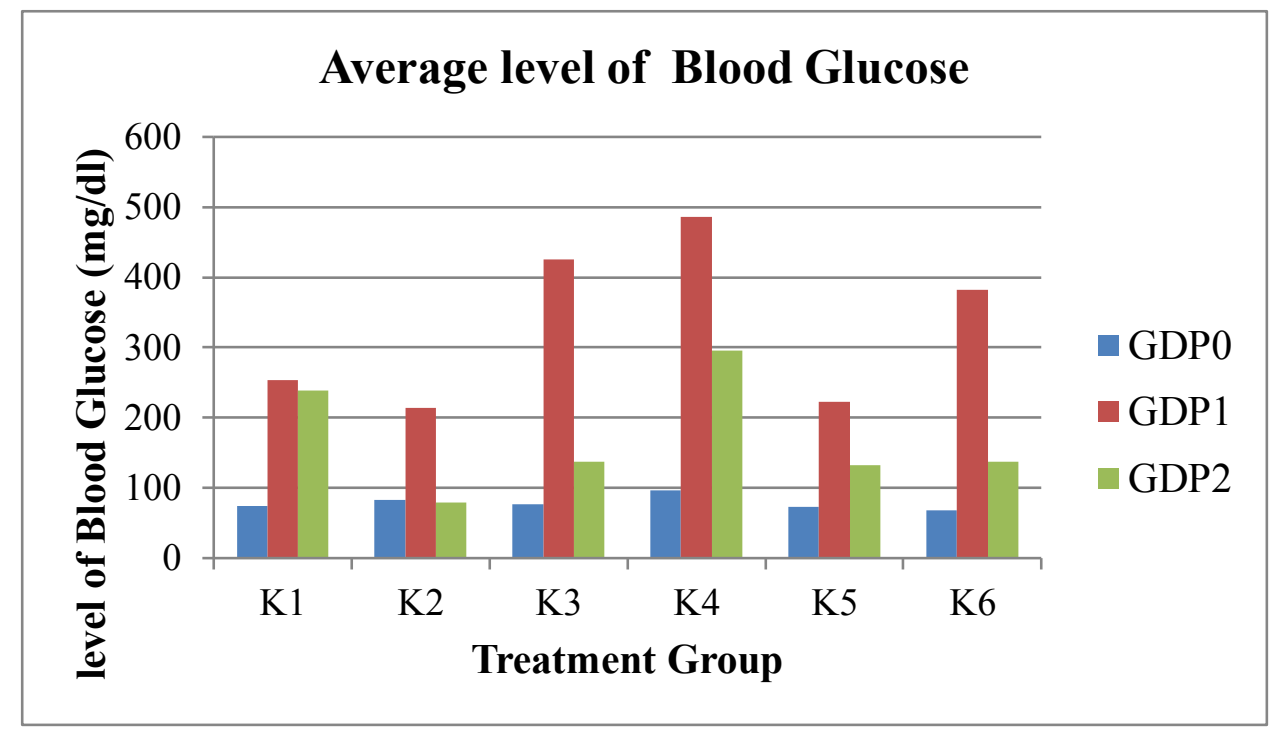

Figure 2. Histogram of Average Level of Mice Blood Glucose

The above histogram shows the existence of different in average level of mice blood glucose on the three times of measurement. GDPO shows the measurement of early fasting blood glucose' level that is before the treatment, which shows that the average level of fasting blood glucose has enormity which almost similar on each group that still stands at the normal level $(<100 \mathrm{mg} / \mathrm{dl})$. The result of measuring GDP1 shows the average level of mice blood glucose begin to increase on each group $(>200 \mathrm{mg} / \mathrm{dl})$, which shows the occurrence of hyperglycemic after inducing monohydrate alloxan as diabetogenic agent. The alloxan selectively can damage $\beta$ cells from Langerhans island with secreted insulin hormone. The work mechanism of alloxan is by putting $\mathrm{Ca}$ ion into mitochondria cell which cause the process of cell oxidation disturbed. Damaging $\beta$ cells of pancreas causes the lowering of insulin secretion (Panjuantiningrum, 2009).

Furthermore, on measurement GDP2 that is after treatment, seen that there are various measurement on each group. The average level of blood glucose on K1 (negative control) still be categorized hyperglycemia. Whereas, on K2 (positive control), K3 
(comparison), the treatment on dosage I, II and III of blood glucose' level had been decreased. The average deviation between GDP1 and GDP2 can be seen on the following histogram :

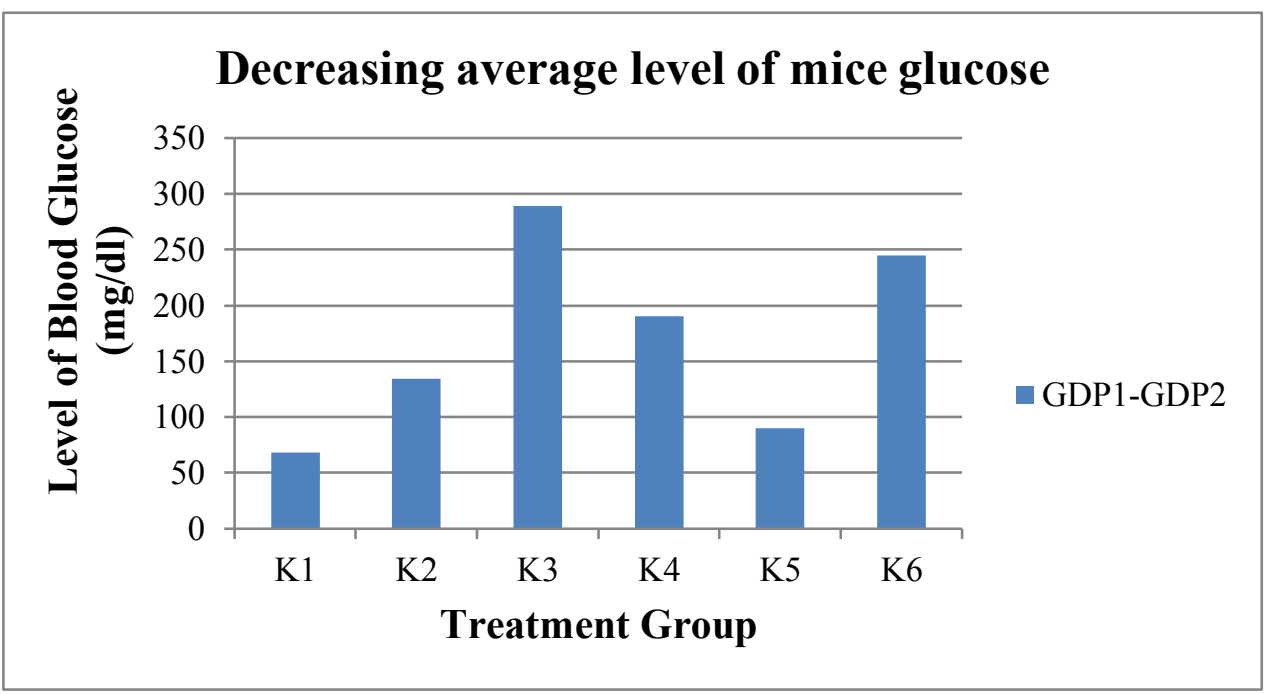

Figure 3. Histogram of decreasing average level of mice glucose (GDP1-GDP2)

Based on above histogram, can be seen the enormity of blood glucose decreasing level on each treatment group. On K1 (negative control) can be known that the occurrence of the lowest blood glucose decreasing level compared to all treatment groups. Whereas on the given treatment of glibenclamide (K2: Positive control), cinnamon extract (K3: comparison), dosage of extract I (K4), dosage II (K5), and dosage of extract III (K6) occurred the large enough decreasing of blood glucose level. This research result shows that by giving infused extract of siam weed leaves can decrease the best blood glucose' level on the concentration $20 \%$. This case can occur because there is antioxidant compound which is had by siam weed leaves. Based on the research which conducted by Marianne et al. (2014), that siam weed leaves have antioxidant and cytoprotection activity. Antioxidant activity can ward off free radicals which occur because of giving alloxan, thus the damage of $\beta$ cells pancreas can be prevented and can repair the function of $\beta$ cells pancreas so after 7 days of extract giving occurred the decreasing of blood glucose' level on each tested animal.

In accordance with the research which conducted by Vijayaraghavan et al. (2013), said that after doing phytochemicals analysis of this siam weed leaves was known that this plant contains various antioxidant compound such as tannin, saponin, flavonoid, beta cyanins, quinones, glycosides, cardioglycosides, terpenoid, phenol, cumarin, steroid, and alkaloid. On this research also was done thephytochemicals test qualitatively and was obtained 4 compounds such as flavonoid, alkaloid, saponin, and tannin. According to Marianne et al. (2014), flavonoid is known as inhibition of hydroxy and superhydroxy radicals which can protect the membrane lipid of $\beta$ cells pancreas toward damaging reaction. According to Widowati (2008), there are some plant mechanisms in lowering blood glucose' level that is the plant has ability as astringent which can precipitate the protein of intestinal mucous membrane and form a layer which protects the intestine, thus can inhibit the glucose' supply and increasing rate of glucose in blood is not too high. Moreover, there is also plant which decreased blood glucose' level by accelerating the secretion of glucose from circulation and by accelerating blood circulation that is through the work of heart and excretion of kidney, thus the secretion rate of urine increased. And there is also plants which accelerate the secretion of glucose through increasing of metabolism or entering into fat deposit. This 
process involves pancreas to produce insulin. According to Subroto (2006), there are 5 activities of plant in healing diabetes. There is a plant with activity to inhibit alpha-glycosidase (inhibitor), the plant with activity to stimulate insulin secretion, there is also a plant with activity to repair the function of insulin, there is also plant which has double activities such as to inhibit alpha-glycosidase and to repair the function of insulin, and also a plant with complex activities such as to decelerate food digestion, to decrease the absorption rate of carbohydrate into the liver circulation, to influence the transport of glucose which is mediated by Nitric Oxide (NO) and to modulate the insulin secretion which mediated by NO. Decreasing of blood glucose occurs because of there is antioxidant compound activity which contained in siam weed leaves such as flavonoid, saponin, tannin, and alkaloid.

From the normality test is obtained the significance Shapiro Wilk as much 0,536 . This result $>0,05$, then data distributed normal. Moreover, on the homogeneity test used Levene Test, the data observed was not homogeny, then was transformed thus was obtained significant score as much 0,082 where higher than $>0,05$ that showed there was homogeny variation, therefore the assumption of ANOVA test's requirement had been fulfilled. The result ANOVA test GDP1-GDP2 (Appendix 5), can be known that the result of ANOVA test was gained $p$-value $>0,05$ is 0,318 then there is no real influence between treatment because $p$ value $>0,05$, thus it cannot be continued with post hoc test ( Duncan $=$ DMRT).

\section{Conclusions}

From the result of research which have been conducted can be concluded that the infused extract of siam weed leaves Eupatorium odoratum L. have potential in lowering the level of blood glucose on male mice Mus musculus L. with the most effective dosage of concentration on concentration $20 \%$.

\section{References}

Halim M. O., S. W. Paini, and T. W. B. Dwi. 2015. The Powder Proportion Influence of Beluntas Leaves (Pluchea indica Less) and Balck Tea Toward Physicochemical, Organoleptic, and Antioxidant Activity from Beverage Product. Jornal of Food and Nutrition Technology.14(1) : $10-16$.

Kirwanto, A. 2014. Controling Effort of Blood Glucose' Level by Using Modification of Bitter Melon Diet on The People with Diabetes Mellitus at Health Clinic Migunani Klaten. Journal of Integrated Health Science. 3(2) : $106-214$.

Kusumaningrum, A., P. Widyaningrum, and I. Mubarok. 2013. Total Reduction in The Bacteria on Chicken Meat with Immersion Infused Bay Leaves (Syzigium polyanthum). Journal of MIPA. 36(1) : $14-19$.

Malangngi, L. P., S. S. Meiske, and J. P. Jessy. 2012. The Content Determination of Tannin and antioxidant activity test from extract of Avocado Seeds (Persea americana Mill.). Journal of MIPA UNSRAT Online. 1(1) : 5-10.

Marianne, D. L. P., Y. S. Elin, F. K. Neng, and N. Rosnani. 2014. Antidiabetic Activity of Leaves Ethanol Extract Chromolaena Odorata (L.) R.M. King on Induced Male Mice With Alloxan Monohydrate. Journal of Natural. 14(1) : $1-4$.

Murthy, K. Shankar, and B. R. Kiran. 2012. Medicinal Plants Used as an Antidiabetic Drug in Pharmacetical Industry and Their Conservation: An Overview. International Research Journal of Pharmacy. 3(10) : 65-71. 
Palijama W., J. Riry, and A. Y. Wattimena. 2012. Weed Community on Plantation of Nutmeg (Myristica fragrans $\mathrm{H}$ ) which Has not Productivity And has Productivity in Hutumuri Villages, Ambon City. Journal Agrologia.1(2) : 134 - 142.

Panjuantiningrum, F. 2009. The Influence of Giving Red Dragon Fruit (Hylocereus polyrhizus) Toward Blood Glucose' Level of white mice which induced by Alloxan', Mini Thesis. Medical Faculty of Sebelas Maret University. Surakarta.

Pasaribu F., S. Panal, and B. Saiful. 2012. Ethanol Extract Test of Mangosteen Peel (Garcinia mangostana L.) toward Decreasing Blood Glucose' Level. Journal of Pharmaceutics and Pharmacology. 1(1): $1-8$.

Prameswari, O. M. and B. W. Simon. 2014. 'Extract Effect's Test of Fragrant Pandan Leaves Water toward Decreasing of Blood Glucose' Level and Histopathology of Mice with Diabetes Melitus. Journal of food and agro-industry, 2(2) : 16- 27.

Radiansah, R., R. Nurdin, and N. Siti. 2013. Extract of Moringa Leaves (Moringa oleivera) as Alternative to Decrease Blood Glucose' Level on Mice. Journal of chemical academics. $2(2): 54-61$.

Raman B. V., A. V. K. Naga, B. R. Narasimha, M. S. Pardha and M. V. R. Basaveswara. 2012. Plants with Antidiabetic Activities and Their Medicinal Values. International Research Journal of Pharmacy. 3(3) : 11 - 15.

Redha, A. 2010. Flavonoid: Structure, Anti Oxidative Property and Its Role in Biological System. Journal of Belian. 9(2) : $196-202$.

Sakika K. A., H. Dedi, A. Suhendi, T. Ika, and S. Broto. 2015. Antidiabetic Activity of Ethanol Extract of Emprit Lempuyang Rizhome (Zingiber amaricans Bl) on White Mice which Induced by Alloxan. Muhammadiyah Surakarta University. Surakarta.

Subroto, M. A. 2006. Herbal Concoctions for Diabetes Melitus. Jakarta. Penebar Swadaya.

Vijayaraghavan, Kavitha, S. A. Mohamed and R. Maruthi. 2013. Studies on Phytochemical Screening and Antioxidant Activity of Chromolaena odorata and Annona squamosa. International Journal of Innovative Research in Science, Engineering and Technology. 2(12) : $7315-7321$.

Widowati, W. 2008. The Potential of Antioxidant as Antidiabetic. JKM. 7(2):1-10.

Wulandari, C. E. 2010. The Influence of Giving Extract Red Onion (Allium ascalonicum) toward Decreasing Blood Glucose Level on Wistar Mice with Hypergyclemia. Medical Faculty. Universitas Diponegoro. Semarang.

Yenti R., A. Ria, and E. P. Agustina. 2014. Cream Formulation from Ethanol Extract of Siam Weed Leaves (Eupatorium Odoratum L.) as Anti Inflamation. Journal of Scientia. 4(1) : 7-11. 